The Agriculturists 14(1): 134-141 (2016) ISSN 2304-7321 (Online), ISSN 1729-5211 (Print)

A Scientific Journal of Krishi Foundation

Indexed Journal

Impact Factor: 0.402 (GIF, 2014)

Review Article

\title{
Natural Plant Products as Eco-friendly Fungicides for Plant Diseases Control- A Review
}

\author{
M. Zaker* \\ Department of Plant Protection Research, Shahrood Agricultural and Natural Resources Research \\ Center, Shahrood, Iran \\ *Corresponding author and Email: masoudzaker35@gmail.com
}

Received: 15 April 2016

Accepted: 12 June 2016

\begin{abstract}
The use of chemical pesticides for controlling various plant diseases is still a common practice especially in developing countries. Although with the application of chemical fungicides, plant diseases can be controlled but the hazardous impacts of such products in human health and environment are well known. Moreover, with their excess applications pest resistance may exist. Natural plant products have been found effective in plant disease managements and could be safely incorporated as suitable alternatives for synthetic fungicides. It is estimated that there are more than 250,000 higher plant species on earth that can be evaluated for their antimicrobial bioactive chemical compounds. During last several decades researchers have evaluated plant extracts and oils against plant pathogens, valuable results have been achieved and some commercially botanical formulations have been prepared and marketed. If we are supposed to move toward production of safer agricultural products, more attention and effort are still needed for production of more commercially botanical fungicides in the near future. The organic agriculture cannot rely on a limited number of commercially pesticides of natural origin, therefore it seems that more researches in formulating more commercially botanical products as fungicides are still needed.
\end{abstract}

Keywords: Organic agriculture, botanical fungicides, plant disease, management

\section{Introduction}

Chemical control of most of fungal diseases of plants may be available and could extensively reduce the impact of plant diseases, but field application of synthetic fungicides may not always be desirable. During the last decades there has been a global awareness that excessive and improper use of chemical fungicides is hazardous to the health of humans, animals, and the environment, therefore an extensive research for environmentally safe and easily biodegradable bio-fungicides is being carried out. Furthermore these compounds are natural in origin, have minimum adverse effects on the physiological processes of plants and are easily convertible into common eco-friendly organic materials (Gnanamanickam, 2002).

Plant extracts, essential oils, gums, resins etc. have been shown to exert biological activity against plant fungal pathogens in vitro and in vivo and can be used as bio-fungicidal products (Fawzi et al., 2009; Jalili et al., 2010; Romanazzi 
et al., 2012). These products are generally assumed to be more acceptable and less hazardous for the ecosystems and could be used as alternative remedies for treatment of plant diseases (Chuang et al., 2007).

Natural plant products have a narrow target range with specific mode of action, therefore are suitable for a specific target, mostly nontoxic for antagonistic microorganisms, show limited field persistence and have a shorter shelf life and no residual threats. They often constitute a part of integrated pest management (IPM) programs, generally safe to humans and environment in comparison to conventional synthetic chemical pesticides. They can easily be adopted by farmers in developing countries who traditionally use plant extracts for the treatment of human diseases (Nuzhat and Vidyasagar, 2013).

It is estimated that there are more than 250,000 higher plant species on the earth offering a vast virtually untapped reservoir of bioactive chemical compounds with many potential uses, including their application as pharmaceuticals and agrochemicals (Cowan, 1999). As in pharmacology, bio-chemicals isolated from higher plants may contribute to the development of natural products for the agricultural industry in three different ways: 1) - by acting as natural pesticides in an unmodified state (crude extracts), 2) - by providing the chemical 'building blocks' necessary to synthesize more complex compounds and 3) - by introducing new modes of pesticidal action that may allow the complete synthesis of novel products in order to counter the problem of resistance to currently used synthetic products by plant pathogenic fungi and bacteria (Cox, 1990).

Many reports approve the efficacy of natural products of plants in controlling fungal growth and mycotoxin production, eg.: cinnamon, clove, oregano, palmarosa and lemongrass oils (Marin et al., 2004), tea tree oil (Burgiel and Smaglowski, 2008), common thyme, cinnamon leaf and aniseed oils (Ćosić et al., 2010), sweet basil, neem, eucalyptus, datura, garlic and oleander extracts (Nashwa and Abo-Elyousr, 2012).

Thymol and carvacrol are definitely the most effective active constituents against most fungal species tested (Numpaque et al., 2011; Shin et al., 2014; Villanueva Bermejo et al., 2015; Gavaric et al., 2015). The mechanism of action of these compounds against fungi is not completely understood but it is supposed to be in relation to their general ability to dissolve or otherwise disrupt the integrity of fungal cell walls and cell membranes (Isman and Machial, 2006). Some more examples regarding antifungal potential of plant products are listed in table 1 .

\section{Chemical composition and mode of action of plant products}

The most commonly plant products used for plant disease management are essential oils and extracts. These two types of plant based products have many similarities but also differ for some characteristics. Essential oils are oily liquids obtained from plants through fermentation, enfleurage and steam distillation (Burt, 2004), whereas plant extracts, in contrast are obtained from dried plant products by filtration and evaporation using various solvents (Wang et al., 2004). The major compounds that have been investigated to date include phenols, flavonoids, quinones, terpenens, tannins, alkaloids, lectins, polypeptides, saponins and sterols (Halama and Van Haluwin, 2004). These products may have fungicidal or fungistatic activity on plant pathogens or they can create conditions unfavourable for establishment and multiplication of pathogenic microorganisms on host plants (Scheuerell and Mahaffee, 2002).

Simple phenols and phenolic acids are bioactive phyto-chemicals consisting a single substituted phenolic ring. Phenolic toxicity to microorganisms is due to the site (s) and number of hydroxyl groups present in the phenolic compound. Quinones are characteristically 
highly reactive, colored compounds with two ketone substitutions in aromatic ring. Flavones, flavonoids and flavonols are phenolic structures with one carbonyl group. They are synthesized by plants in response to microbial infection and are often found effective in vitro as antimicrobial substance against a wide array of microorganisms. Tannins are polymeric phenolic substances possessing the astringent property (Figure 1). These compounds are soluble in water, alcohol and acetone (Gurjar et al., 2012). The mechanisms of some important natural compounds on plant pathogenic fungi are given in table 2.
Species of some plant families such as Solanaceae for their high alkaloid contents, Mimosaceae for their high tannins contents and Lamiaceae and Meliaceae for their wide diversity of terpenoids may be more feasible for investigations regarding their biofungicidal compounds. For production of active ingredients, there are some factors that determine variability in quality and quantity of metabolites. The concentration of a chemical in different parts of a plant such as roots, leaves, flowers and fruits may differ. It may even be absent in one or more parts, therefore it is convenient to collect integral samples (Montes-Belmont and Carvajal, 1998).

Table 1. Fungicidal properties of some of plant products

\begin{tabular}{|c|c|c|}
\hline Name of plant product /compound & Controlled plant pathogen & Reference \\
\hline $\begin{array}{l}\text { Acacia, sapodilla, datura, eucalyptus, } \\
\text { pomegranate and black plum extracts }\end{array}$ & $\begin{array}{l}\text { Aspergillus candidus, } A . \\
\text { flavus, } A . \text { fumigatus, } A . \\
\text { niger, } \text { A. ochraceus }\end{array}$ & Satish et al. (2007) \\
\hline Eucalyptus and lavender extracts & Alternaria alternata & $\begin{array}{l}\text { Zaker and } \\
\text { Mosallanejad (2010) }\end{array}$ \\
\hline $\begin{array}{l}\text { Clove bud, cinnamon, ginger, black pepper, } \\
\text { garlic and onion extracts }\end{array}$ & Aspergillus niger & Avasthi et al. (2010) \\
\hline $\begin{array}{l}\text { Neem, chinaberry, garlic and turmeric } \\
\text { extracts }\end{array}$ & $\begin{array}{l}\text { Fusarium oxysporum, } \\
\text { Rhizoctonia solani }\end{array}$ & Hadian (2012) \\
\hline Artemisia, thyme and eucalyptus extracts & Fusarium solani & Zaker (2014) \\
\hline $\begin{array}{l}\text { Indian beech, milk weed, oleander and } \\
\text { turmeric extracts }\end{array}$ & $\begin{array}{l}\text { Aspergillus fumigatus, } \\
\text { Alternaria solani, } \\
\text { Helminthosporium spp. }\end{array}$ & Masih et al. (2014) \\
\hline Kokum, wild turmeric and jasmine extracts & $\begin{array}{l}\text { Rhizopus stolonifer, } \\
\text { Colletotrichum coccodes }\end{array}$ & $\begin{array}{l}\text { Bhagwat and Datar } \\
\text { (2014) }\end{array}$ \\
\hline $\begin{array}{l}\text { Grape seed, thyme, rosemary, mint, basil } \\
\text { and sage essential oils }\end{array}$ & Botrytis cinerea & $\begin{array}{l}\text { Mermer-Doğu and } \\
\text { Zobar (2014) }\end{array}$ \\
\hline $\begin{array}{l}\text { Anise, cumin, caraway, ammin, pennyroyal, } \\
\text { thyme and cinnamon essential oils }\end{array}$ & $\begin{array}{l}\text { Aspergillus flavus, Phoma } \\
\text { sorghina, Alternaria } \\
\text { alternata, Botrytis cinerea }\end{array}$ & Behdani et al. (2012) \\
\hline $\begin{array}{l}\text { Pepper and cassia extracts, neem, mustard } \\
\text { and cinnamon essential oils }\end{array}$ & Phytophthora nicotianae & $\begin{array}{l}\text { Bowers and Locke } \\
\text { (2004) }\end{array}$ \\
\hline Citral, eugenol and geraniol & $\begin{array}{l}\text { Fusarium moniliforme, } \\
\text { Curvularia lunata }\end{array}$ & $\begin{array}{l}\text { Krishna Kishore et al. } \\
\text { (2007) }\end{array}$ \\
\hline $\begin{array}{l}\text { Carvacrol, eugenol, citronellol, geraniol, } \\
\text { citral, perillyl and menthol }\end{array}$ & $\begin{array}{l}\text { Monilinia fructicola, } \\
\text { Botrytis cinerea }\end{array}$ & Tsao and Zhou (2000) \\
\hline $\begin{array}{l}\text { Thymol, carvacrol, 1,8 cineole, Y-terpinene, } \\
\text { p-cymene and anethole }\end{array}$ & $\begin{array}{l}\text { Fusarium moniliforme, } \\
\text { Rhizoctonia solani, } \\
\text { Phytophthora capsici }\end{array}$ & $\begin{array}{l}\text { Mueller-Riebau et al. } \\
\text { (1995) }\end{array}$ \\
\hline
\end{tabular}




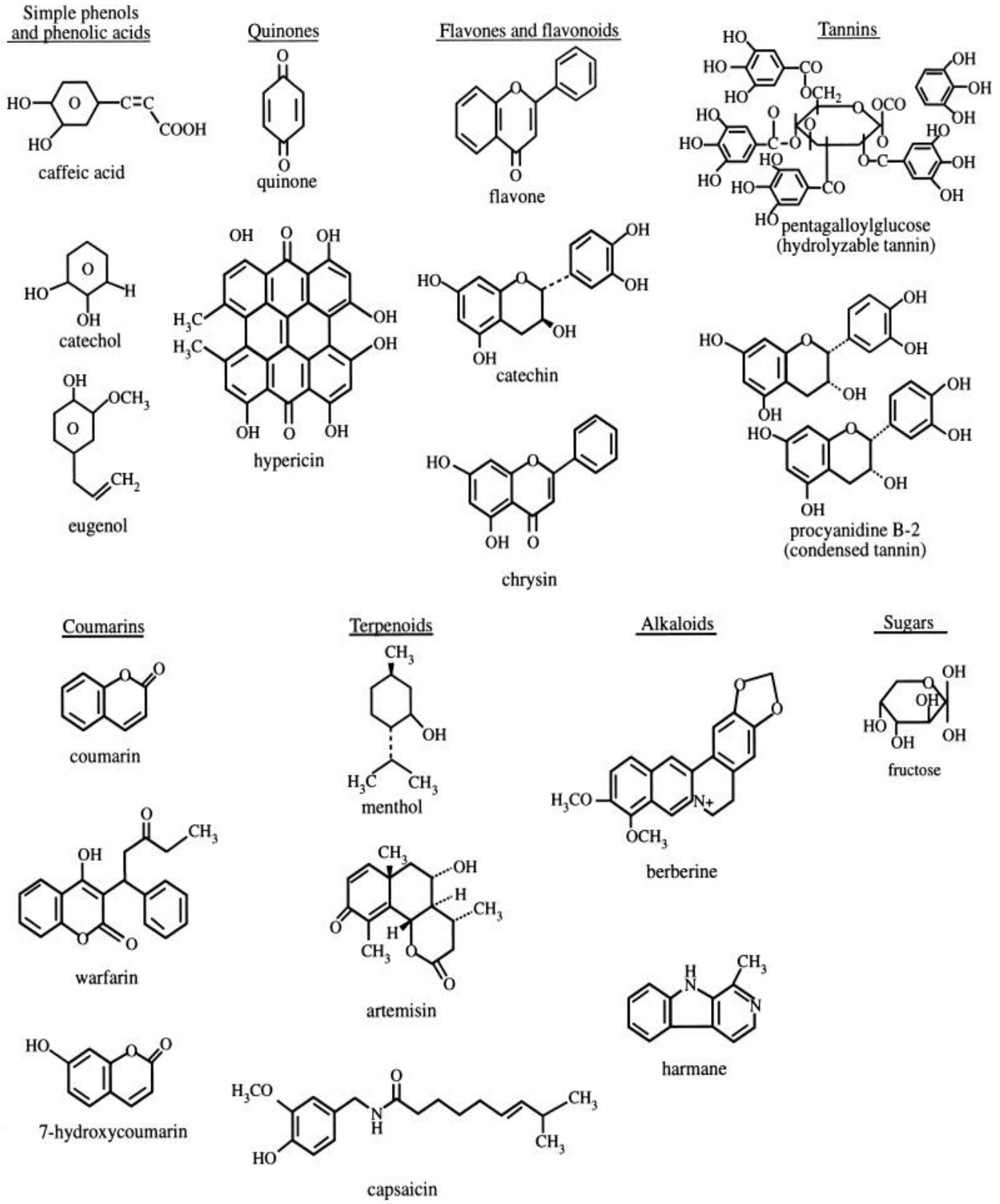

Figure 1. Chemical structures of main groups of natural compounds (Cowan, 1999) 
Table 2. Mechanisms of action of phytochemicals (Cowan, 1999)

\begin{tabular}{ll}
\hline Name of compound & \multicolumn{1}{c}{ Mode of action } \\
\hline Simple Phenols & Membrane disruption, substrate deprivation \\
Phenolic acids & Bind to adhesins, complex with cell wall, inactivate enzymes \\
Terpenoids & Membrane disruption \\
Essential oils & Membrane disruption \\
Alkaloids & Intercalate into cell wall \\
Tannins & Bind to proteins, enzyme inhibition, substrate deprivation \\
Flavonoids & Bind to adhesins, complex with cell wall, Inactivate enzymes \\
Coumarins & Interaction with eucaryotic DNA \\
Lectins & Form disulfide bridges \\
Polypeptides & Form disulfide bridges \\
\hline
\end{tabular}

\section{Current aspects of commercially available natural products}

Although considerable research efforts throughout the world have been conducted and an ever-increasing volume of scientific literature on the pesticidal properties of plant products and their constituents are available, but some pest control products based on plant essential oils/extracts have been appearing in the market which seems not enough for substituting with current synthetic pesticides.

In the United States, commercial development of insecticides based on plant essential oils/extracts has been greatly facilitated by exemption from registration for certain oils commonly used in processed foods (Quarles, 1996). This opportunity has encouraged the development of some essential oil-based pesticides using rosemary oil, clove oil, and thyme oil as active ingredients for agricultural and industrial applications. Application of these products has been interesting, particularly for control of greenhouse pests and diseases.

The natural plant product Milsana ${ }^{\circledR}$, extracted from the giant knotweed (Reynoutria sacchalinensis) is probably the best known natural fungicide. This product has been reported to control powdery mildew, caused by Sphaerotheca fuliginea, in the long English cucumber under greenhouse conditions, and also showed broad spectrum activity against powdery mildew of tomato, apple and begonia as well as downy mildew of grapevine and rust of bean (Daayf et al., 1995). A product based on rosemary oil is available fungicide sold under the trade name 'Sporan ${ }^{\mathrm{TM}}$. A volatile natural product, Carvone ${ }^{\mathrm{TM}}$, derived from dill and caraway seed, has been developed to inhibit the growth of storage pathogens (Moezelaar et al., 1999). Carvone $\mathrm{T}^{\mathrm{TM}}$ is currently marketed as Talent $^{\circledR}$ in the Netherlands. Additionally, Fungastop $^{\mathrm{TM}}$ and Armorex ${ }^{\mathrm{TM}}$ II, are two natural products developed in the USA by Soil Technologies Corp., and are commercially available for the control of various plant diseases in agriculture. TimorexGold ${ }^{\circledR}$ manufactured by Stockton group (Switzerland) is the new generation of bio-fungicides based on a plant extract of Melaleuca alternifolia for the control of powdery mildews, downy mildews, rust and early and late blight diseases in vegetables, grapevines and orchards and is harmless to beneficial insects and bees. For organic farming also some plant essential oils are marketed as fungicides. These include E-Rase ${ }^{\mathrm{TM}}$ from jojoba (Simmondsia californica) oil, Sporan ${ }^{\mathrm{TM}}$ from rosemary (Rosemarinus officianalis) oil, Promax $^{\mathrm{TM}}$ from thyme (Thymus vulgaris) oil, Trilogy ${ }^{\mathrm{TM}}$ from neem (Azadirakhta indica) oil and $\mathrm{GC}-3^{\mathrm{TM}}$ being a mixture of cottonseed (Gossypium hirsutum) oil and garlic (Allium 
sativum) extract. Bla- $\mathrm{S}^{\mathrm{TM}}$ is used against rice blast disease in eastern Asia, Kasugamin ${ }^{\mathrm{TM}}$, against rice blast and other crop diseases in Japan, Mildiomycin ${ }^{\mathrm{TM}}$, for controlling powdery mildews mainly in Japan, Delvolan ${ }^{\mathrm{TM}}$, against fungal diseases of ornamental plants and Validacin $^{\mathrm{TM}}$, for controlling Rhizoctonia root rot of a variety of crops (Dayan et al., 2009).

\section{Conclusions}

Due to hazardous impact of most of synthetic fungicides, in the near future the use of such chemicals must be strictly regulated by governments which may lead to a growing demand for biologically plant protection materials such as plant origin products. Based on approved data and scientific publications it seems evident that plant essential oils/extracts are biodegradable and do not cause similar environmental risks like widely used synthetic chemicals. The option of replacing fossil oilbased chemicals with plant product formulations fits well with food and agriculture policies directed to the future. Sustainable agriculture and food security cannot rely on the use of fossil oil as has been the case for a long time in the developing countries. Local resources should be utilized and thus production of more biopesticides should become a common practice.

\section{References}

Avasthi, S., Gautam, A. K. and Bhadauria, R. 2010. Antifungal activity of plant products against Aspergillus niger: A potential application in the control of a spoilage fungus. Biological Forum- An International Journal, 2(1): 53-55.

Behdani, M., Pooyan, M. and Abbasi, S. 2012. Evaluation of antifungal activity of some medicinal plants essential oils against Botrytis cinerea, causal agent of postharvest apple rot, in vitro. International Journal of Agriculture and Crop Sciences, 4(14): 1012-1016.
Bhagwat, M. K. and Datar, A. G. 2014. Antifungal activity of herbal extracts against plant pathogenic fungi. Archives of Phytopathology and Plant Protection, 47(8): 959-965.

Bowers, J. H. and Locke, J. C. 2004. Effect of formulated plant extracts and oils on population density of Phytophthora nicotianae in soil and control of Phytophthora blight in the greenhouse. Plant Disease, 88: 11-16.

Burgiel, Z. J. and Smaglowski, M. 2008. Fungistatyczne właściwości olejku z drzewa herbacianego [Fungistatic properties of tea tree oil]. Zesz. Probl. Post. Nauk Roln. 529: 13-18.

Burt, S. 2004. Essential oils: their antibacterial properties and potential applications in foods, a review. International Journal of Food Microbiology, 94: 223-253.

Chuang, P. H., Lee, C. W., Chou, J. Y., Murugan, M., Shieh, B. J. and Chen, H. M. 2007. Antifungal activity of crude extracts and essential oil of Moringa oleifera Lam. Bioresource Technology, 98:232-236.

Ćosić, J., Vrandečić, K., Postic, J., Jurković, D. and Ravlić, M. 2010. In vitro antifungal activity of essential oils on growth of phytopathogenic fungi. Poljoprivreda, 16: (2) $25-28$.

Cowan, M. M. 1999. Plant products as antimicrobial agents. Clinical Microbiology Reviews, 12: 564-582.

Cox, P. A. 1990. Ethnopharmacology and the search for new drugs. In: Bioactive compounds from plants. Chadwick D. J. \& Marsh, J. (eds.), John Willey, Chichester, UK, 40-55 pp.

Daayf, F., Schmitt, A. and Bèlanger, R. R. 1995. The effects of plant extracts of Reynoutria sachalinensis on powdery mildew development and leaf physiology of long 
English cucumber. Plant Disease, 79: 577-580.

Dayan, F. E., Cantrell, C. L. and Duke, S. O. 2009. Natural products in crop protection. Bioorganic and Medicinal Chem., 17 (12): 4022-4034.

Fawzi, E. M., Khalil, A. A. and Afifi, A. F. 2009. Antifungal effect of some plant extracts on Alternaria alternata and Fusarium oxysporum. African Journal of Biotechnology, 8(11): 2590-2597.

Gavaric, N., Mozina, S. S., Kladar, N. and Bozin, B. 2015. Chemical Profile, Antioxidant and Antibacterial Activity of Thyme and Oregano Essential Oils, Thymol and Carvacrol and Their Possible Synergism. Journal of Essential Oil Bearing Plants, 18(4): 1013-1021.

Gnanamanickam, S. S. 2002. Biological control of crop diseases. Marcel Dekker Inc., New York, USA, 468 p.

Gurjar, M. S., Ali, S., Akhtar, M. and Singh, K. S. 2012. Efficacy of plant extracts in plant disease management. Agricultural Sciences, 3(3): 425-433.

Hadian, S. 2012. Antifungal activity of some plant extracts against some plant pathogenic fungi in Iran. Asian Journal of Experimental Biological Sciences, 3(4): 714-718.

Halama, P. and Van Haluwin, C. 2004. Antifungal activity of lichen extracts and lichenic acids. BioControl, 49: 95-107.

Isman, M. B. and Machial, C. M. 2006. Pesticides based on plant essential oils: from traditional practice to commercialization. In: Naturally occurring bioactive compounds. Rai, M. \& Carpinella, M. C. (eds.). Elsevier, Amsterdam, Netherlands, 29-44 pp.

Jalili-Marandi, R., Hassani, A., Ghosta, Y., Abdollahi, A., Pirzad, A. and Sefidkon, F. 2010. Thymus kotschyanus and Carum copticum essential oils as botanical preservatives for table grape. Journal of Medicinal Plants Research, 4(22): 24242430.

Krishna Kishore, G., Pande, S. and Harish, S. 2007. Evaluation of essential oils and their components for broad-spectrum antifungal activity and control of late leaf spot and crown rot diseases in peanut. Plant Disease, 91(4): 375-379.

Marin, S., Velluti, A., Ramos, A. J. and Sanchis, V. 2004. Effect of essential oils on zearalenone and deoxynivalenol production by Fusarium graminearum in non-sterilized maize grain. Food Microbiology, 21: 313-318.

Masih, H., Peter, J. K. and Tripathi, P. A. 2014. Comparative evaluation of antifungal activity of medicinal plant extracts and chemical fungicides against four plant pathogens. International Journal of Current Microbiology and Applied Sciences, 3(5): 97-109.

Mermer-Doğu, D. and Zobar D. 2014. Effects of some plant essential oils against Botrytis cinerea and Tetranychus urticae on grapevine. Turkish Journal of Agricultural and Natural Science, Special Issue 1: 1268-1273.

Moezelaar, R., Braam, C., Zomer, J., Gorris, L. G. M. and Smid, E. J. 1999. Volatile plant metabolites for postharvest crop protection. In: Modern Fungicides and Antifungal Compounds II, $1^{\text {st }} e d$, Lyr, H., Russell, P. E., Dehne, H. W. and Sisler, H. D. (eds.). Intercept Limited, USA, 453$467 \mathrm{pp}$.

Montes-Belmont, R. and Carvajal, M. 1998. Control of Aspergillus flavus in maize with plant essential oils and their components. Journal of Food Protection, 61(5): 616-619.

Mueller-Riebau, F., Berger, B. and Yegen, O. 1995. Chemical composition and 
fungitoxic properties to phytopathogenic fungi of essential oils of selected aromatic plants growing wild in Turkey. Journal of Agricultural and Food Chemistry, 43: 2262-2266.

Nashwa, S. M. A. and Abo-Elyousr, K. A. M. 2012. Evaluation of various plant extracts against the early blight disease of tomato plants under greenhouse and field conditions. Plant Protection Science, 48 (2): 74-79.

Numpaque, M. A., Oviedo, L. A., Gil, J. H., García, C. M. and Durango, D. L. 2011. Thymol and carvacrol: biotransformation and antifungal activity against the plant pathogenic fungi Colletotrichum acutatum and Botryodiplodia theobromae. Tropical Plant Pathology, 36 (1): 3-13.

Nuzhat, T. and Vidyasagar, G. M. 2013. Antifungal investigations on plant essential oils. A review. International Journal of Pharmacy and Pharmaceutical Sciences, 5(2): 19-28.

Quarles, W. 1996. EPA exempts least-toxic pesticides. IPM Practice, 18: 16-17.

Romanazzi, G., Lichter, A., Gabler, F. M. and Smilanick, J. L. 2012. Recent advances on the use of natural and safe alternatives to conventional methods to control postharvest gray mold of table grapes. Postharvest Biology and Technology, 63:141-147.

Satish, S., Mohana, D. C., Raghavendra, M. P. and Raveesha, K. A. 2007. Antifungal activity of some plant extracts against important seed borne pathogens of Aspergillus sp. Journal of Agricultural Technology, 3(1): 109-119.
Scheuerell, S. and Mahaffee, W. 2002. Compost tea: Principles and prospects for plant disease control. Compost Science \& Utilization, 10: 313-338.

Shin, M. H., Kim, J. H., Choi, H. W., Keum, Y. S. and Chun, S. C. 2014. Effect of Thymol and Linalool fumigation on postharvest diseases of table grapes. Mycobiology, 42(3): 262-268.

Tsao, R. and Zhou, T. 2000. Antifungal activity of monoterpenoids against postharvest pathogens Botrytis cinerea and Monilinia fructicola. Journal of Essential Oil Research, 12: 113-121.

Villanueva Bermejo, D., Angelov, I., Vicente, G., Stateva, R. P., Rodriguez GarcíaRisco, M., Reglero, G., Ibañez, E. and Fornari, T. 2015. Extraction of thymol from different varieties of thyme plants using green solvents. Journal of the Science of Food and Agriculture, 95(14):2901-2907.

Wang, W., Ben-Daniel, B. H. and Cohen, Y. 2004. Control of plant diseases by extracts of Inula viscosa. Phytopathology, 94: 1042-1047.

Zaker, M. and Mosallanejad, H. 2010. Antifungal activity of some plant extracts on Alternaria alternata, the causal agent of alternaria leaf spot of potato. Pakistan Journal of Biological Sciences, 13(21): 1023-1029.

Zaker, M. 2014. Antifungal evaluation of some plant extracts in controlling Fusarium solani, the causal agent of potato dry rot in vitro and in vivo. International Journal of Agriculture and Biosciences, 3(4): 190195. 